\title{
Socialising economic relationships: a critique of business regulation - introduction
}

\author{
BETTINA LANGE \\ Centre for Socio-Legal Studies, Oxford University
}

\begin{abstract}
Reforming business regulation?
$\mathrm{T}$

The 2008 financial crisis and the continuing global economic downturn raise urgent and important questions about the capacity of legal regulation, first and foremost to control business activity, but also to promote economic growth. The editors of this special issue thus seek to explore the contribution of socio-legal scholarship to regulatory reform debates. We want to develop a debate that transcends the dichotomy between "more and better" state regulation and faith in self-regulating markets. We therefore organised in April 2010 a workshop at the Centre for Socio-Legal Studies, Oxford University ${ }^{1}$ that discussed the opportunities for and limits to socialising economic relationships as a tool for both regulating and enabling business activity. The work of the nineteenth and early twentiethcentury economic sociologist, anthropologist and historian, Karl Polanyi, provided a key reference point.

Karl Polanyi analysed, in his classic study The Great Transformation, ${ }^{2}$ various ways of organising economic activity across a range of contexts, including tribal societies in Western Melanesia, medieval European economies, mercantilism and, most importantly, industrial capitalism in eighteenth and nineteenth-century England. Polanyi argued that industrial capitalism in England was associated with a disembedding of economic out of social relationships. It gave rise to the "market society" in which society becomes a mere adjunct to the operation of markets. ${ }^{3}$ Polanyi therefore perceived industrial capitalism as a radical break with previous forms of organising, including regulating economic exchange, such as
\end{abstract}

1 We gratefully acknowledge financial support for this workshop by the UK Socio-Legal Studies Association through its annual seminar competition. We also thank a number of colleagues who contributed to the discussions and commented on draft papers: Anthony Bradney, Christopher Decker, Tricia Feeney, Tom Gibbons, Paddy Ireland, Angus Johnston, Kieran Kelly and Mike Varney. A selection of papers from the workshop is published in this special issue of the NILQ.

2 K Polanyi, The Great Transformation: The political and economic origins of our time (Boston: Beacon Press 1944).

3 Ibid. p. 74. 
"redistribution", 4 "householding" 5 and "reciprocity". ${ }^{6}$ His account of the rise of industrial capitalism includes a harrowing portrayal of the social side-effects of this great transformation, ${ }^{7}$ such as poor living conditions of urban workers and the loss of dignity of an unemployed reserve army of labour, driven off the land during the enclosures, but kept alive by parishes through basic poor law relief.

Polanyi's key contribution to regulation studies is his claim that self-regulating markets are a myth and that society will ultimately always reassert itself and control the conduct of economic activity. He argues that the disembedding of economic out of social relationships, for instance, through the rise of markets in the fictitious commodities of land, labour and money, is always accompanied by a counter-movement through which society re-embeds economic relationships into social norms. Hence, our workshop sought to explore what such a counter-movement may look like in the context of contemporary UK business regulation. Are we really witnessing a rise in socialised economic activity, facilitated through co-operatives, stewardship models of shareholding and "open corporations" that seek to mitigate their social and environmental impacts? Is state regulation which limits competition in some markets on public interest grounds an example of re-embedding economic into social relationships? What does socialising economic activity actually entail and what are its regulatory consequences?

\section{Why Polanyi?}

We chose Polanyi's work as the starting point for our workshop because his sociological approach departs from Marxist economic determinism and neoclassical economics. The latter has been predominant in contemporary public policy debates and also influential in North-American regulation studies. But we also critically interrogate Polanyi's work in the context of contemporary regulation. Since Polanyi wrote The Great Transformation in the early $1940 \mathrm{~s}^{8}$ globalisation has accelerated and intensified. "Embedding economic in social relationships" is potentially becoming more difficult given increased international mobility of capital and a lack of consensus - in a highly pluralistic "world society" - about the social norms in which economic activity should be embedded.

\section{From public policy debates to an economic sociology of law}

This special issue contributes to two interlinked debates. First, a public policy debate initiated by the current UK conservative-liberal Coalition government explores how the vision of a "Big Society" can be realised. This debate examines how the role of social enterprises and voluntary organisations can be increased, not only for generating business activity, but also for providing welfare services, a "counter-regulatory move" that addresses the social side effects of a market-based economic system. The current UK government's

4 Redistribution involves the storage of agricultural produce by community leaders. Thus, it is a form of taxation for public purposes, or can be used for the defence of the community, or enables foreign trade when exchanged with other groups (Polanyi, The Great Transformation, n. 2 above, p. 50).

5 Householding involves organising economic needs and productive capacities around the kinship or employment bonds of a family unit, settlement or the manor.

6 Reciprocity involves organising garden and household economy through social relationships among the members of a community who produce for "non-economic ends", such as display of skill in agricultural production and free gifts (Polanyi, The Great Transformation, n. 2 above, pp. 48-9).

7 Polanyi also uses the term transformation to refer to the failure of market society and the rise of fascism in the 1930s in Germany. S Frerichs "Re-embedding neo-liberal constitutionalism: a Polanyian case for the economic sociology of law" in C Joerges and J Falke (eds), Karl Polanyi, Globalisation and the Potential of Law in Transnational Markets (Oxford: Hart 2011), p. 72.

8 F Block, "Karl Polanyi and the writing of The Great Transformation" (2003) 32(3) Theory and Society 276. 
Big Society initiative ${ }^{9}$ claims to empower citizens and communities in a way that seems to chime with Polanyi's assertion of the democratic primacy of society. The Big Society ${ }^{10}$ programme seeks to strengthen the role of the third sector, such as charities, voluntary organisations, mutuals, ${ }^{11}$ co-operatives and social enterprises, in delivering and regulating public services in particular at a local level, as well as in rekindling economic growth. But the UK government's Big Society agenda diverges from Polanyi's idea of embedding economic into social relationships in three key regards. First, it deregulates. In particular, traditional legal employment, contract and administrative regulations (e.g. licensing) are proposed to be relaxed for third-sector organisations, in order to facilitate their development. Second, while Polanyi was highly critical of self-regulating markets as the dominant form for organising economic activity, the UK government does not envisage third-sector models of organising and regulating economic activity to replace markets. For instance, the newly set up ${ }^{12}$ Big Society bank - called Big Society Capital - which is in fact not a licensed bank but a vehicle for developing social investment funds ${ }^{13}$ - seeks to stimulate a "sustainable market in social investment" in the UK, including "social impact bonds"14 and a secondary market in social investment securities. Big Society Capital seeks to facilitate social entrepreneurs' access to conventional capital markets. Third, in contrast to Polanyi's emphasis on co-operative social relationships framing economic activity, for instance, in the case of redistribution and reciprocity, the market-inspired principle of competition is at the heart of the UK government's Big Society approach towards regulation, public services and economic growth. For example, third sector organisations will have to compete with state public service providers and private businesses when tendering for the delivery of welfare state services.

Hence, the UK government's Big Society vision constitutes a particular way of thinking about relationships between economy, society, the state and law. Different ways of thinking about such relationships are opened up, secondly, through debates in the developing field of the economic sociology of law. ${ }^{15}$ Economic sociology of law ${ }^{16}$ questions the rhetorical

9 This Big Society discourse is being institutionalised through an Office of Civil Society which has been set up as part of the Cabinet Office and which is supported through a Minister for the Big Society who is responsible for charities, social enterprises and voluntary organisations.

10 While Polanyi defines society in terms of a national policy, the Conservative-Liberal UK Coalition government understands society in narrow and potentially parochial terms as "families, networks, neighbourhoods and communities" (Building the Big Society, the government's Big Society programme, at www.cabinetoffice.gov.uk/content/big-society-useful-links, p. 1).

11 Such as public sector mutual joint ventures through which public sector employee co-owned organisations are established that deliver public services. An example of this is My Civil Service Pension (MyCSP) which provides civil service pension administration. These mutual joint ventures can include private companies. The operation of these public sector joint mutuals reflects Big Society themes: 1\% of MyCSP net profits will be paid to charities and community projects nominated by employee partners, $1 \%$ of partners' time will be spent on local charity and community projects and $1 \%$ of its staff will be apprentices and interns. Public sector mutual joint ventures expand the contracting-out agenda of previous UK governments by now including the third sector in the delivery of public services.

12 Launched on 29 July 2011.

13 Such as venture funds, community asset funds, property funds and microfinance funds.

14 "The Big Society Bank: outline proposal", May 2011, at: www.cabinetoffice.gov.uk/content/big-societycapital, p. 5.

15 See e.g. R Swedberg, "The case for an economic sociology of law" (2003) 32 Theory and Society 1-37; Frerichs, "Re-embedding neo-liberal constitutionalism", n. 7 above, p. 66; J Caporaso and S Tarrow, Polanyi in Brussels: European Institutions and the Embedding of Markets in Society, RECON Online Working Paper 2008/01, www.reconproject.eu.

16 Defined as "a sociological analysis of the role of law in economic life", R Swedberg, "The case for an economic sociology of law”, n. 15 above, p. 1. 
images of economic life. It develops careful empirical and theoretical accounts of how specific legal concepts which frame economic life, such as property, both private and communal, the corporation and contracts, are sociologically constituted. ${ }^{17}$ This special issue seeks to demonstrate the value of linking sociology of law and economic sociology in the newly developing field of economic sociology of law. While sociology of law has already made a significant contribution to understanding business regulation, for instance, by drawing attention to the social processes that inform the development and enforcement of state law and which help to explain why "business law in action" takes the form it does, ${ }^{18}$ this is not quite the case for economic sociology. As the contributions to this special issue show, theoretical and empirical sociological analysis of actual business behaviour renders explicit what role political institutions, ${ }^{19}$ social interactions, ${ }^{20}$ norms ${ }^{21}$ and networks ${ }^{22}$ play in regulating production and consumption. Hence, an economic sociology of law provides a fertile ground for a critique of contemporary UK business regulation and UK public policy debates about the Big Society. This special issue thus contributes to both normative and analytical debates within an economic sociology of law, by probing the normative claim that business regulation should seek to embed economic into social relationships that express the interests of whole "communities of fate", rather than merely those of rational individual economic actors. It also addresses the analytical claim that some UK business regulation already involves an embedding of economic into social relationships.

\section{Socialising economic relationships through contemporary UK business regulation?}

The articles in this special issue comprehensively shed light on Polanyi's idea of embedding economic into social relationships because they examine a range of different business activities, including those of the private modern corporation that trades in competitive markets as well as state-subsidised corporate activity, such as that of the BBC and the new Lloyds banking group, which has been recapitalised by the British taxpayer. ${ }^{23}$

Part I of the special issue starts off with a conceptual discussion of what "embedding economic into social relationships" actually means by critiquing Polanyi's work with reference to Roger Cotterrell's contemporary sociology of law and Karl Marx's social theory. Amanda Perry-Kessaris argues that we can understand more about the role of law in promoting the embedding of economic into social relationships if we see law through Cotterrell's "lens of community". Communities, often internally pluralistic and potentially conflictual, are recognised as shaping whether and how state law can regulate business behaviour. Amanda Perry-Kessaris thus links in an innovative way contemporary sociology of law debates about law's grounding in community bonds with an economic sociology perspective that maps how business activity becomes disembedded out of social

17 Swedberg, "The case for an economic sociology of law", n. 15 above, pp. 12, 29.

18 And thereby provides an important critique of the influence of economic analysis of law, informed by neoclassical economics, on regulation studies.

19 See, for instance, N Fligstein, "Markets as politics: a political-cultural approach to market institutions" (1996) 61(4) American Sociological Review 656-73.

20 See, e.g. Swedberg's discussion of the development of a medieval lex mercatoria which emerged out of merchants' practices, for instance, during the Champagne Fairs in France. Swedberg, "The case for an economic sociology of law", n. 15 above, p. 13.

21 V Zelizar, Markets and Morals (Princeton, NJ: Princeton University Press 1983).

22 M Granovetter, "Economic action and social structure: the problem of embeddedness" (1985) 91(3) American Journal of Sociology 481-510.

23 Part II examines the corporate economy, while Part III discusses hybrid economic actors that straddle the distinction between the corporate and the state economy. This special issue leaves for further analysis the household economy and the significant role of gender in shaping its economic relationships. Swedberg, "The case for an economic sociology of law", n. 15 above, pp. 15, 29. 
relationships and potentially threatens the survival of communities. The World Bank's Investment Climate Programme and the securitisation practices leading up to the 2008 financial crisis serve as two highly topical examples of disembedding in her analysis.

The next article by Grietje Baars provides a thought-provoking radical critique of what she considers as Polanyi's rather limited regulatory reform agenda. She questions his claim that state law can make a significant contribution to the embedding of economic into social relationships, on the grounds that law itself reflects the commodity form. She also casts doubt on the very idea of corporate social responsibility - a potential example of embedding economic into social relationships - because it "marketises morality". Her article thus engages with a key dilemma: is law dependent on society and economy or can it independently shape economic and political activity?

The following five articles in Part II present a range of specific case studies about the legal regulation of corporate actors with a view to identifying opportunities for and limits to "embedding economic into social relationships". The first two articles, by Wilson and Talbot discuss UK company law, while the three following, by Marzo, McCormack and Thomas, consider how transnational legal and organisational frameworks affect the way corporate actors conduct business. Wilson continues an incisive critique - begun by Baars - of the modern corporation as disembedding economic out of social relationships. $\mathrm{He}$ further develops a Polanyian analysis by suggesting that Ulrich Beck's notion of risk regulation in reflexive modernity is the contemporary way of thinking about "embedding economic into social relationships". He charts a change in the conception of the modern corporation from the nineteenth-century vision of the limited liability company as a relatively autonomous economic entity, distinct from the social sphere, to a conception of the corporation in the twenty-first century that seeks to open it up to the social sphere. Despite its potential to do so, given current evidence of limited shareholder activism, he doubts, however, whether s. 172 of the Companies Act 2006 will push directors to do much to remedy the impact of their companies on the environment and the community.

Like Wilson, Talbot, in the next article, is sceptical about the prospects for shareholder activism and its capacity to re-embed the corporation into social relationships. She argues, as Baars and Thomas do, that socialising economic activity will be limited if economic life is mainly organised through markets which are based on private, including financial, property. She suggests that the contribution of a stewardship model of shareholding to socialising economic relationships is limited because it has to operate within a system of corporate governance that is geared towards profit maximisation.

Marzo's article further updates Polanyian analysis by considering techniques for embedding economic into social relationships in a transnational sphere, beyond the nation state. She analyses international framework agreements (IFAs) as voluntary regulation of labour standards shaped by power relationships between multinational companies and international trade unions. Her legal analysis of the nature and enforceability of IFAs prompts us to think about what needs to happen in order for economic relationships to become really "embedded" in social relationships.

McCormack's article continues the analysis of business regulation in a transnational sphere. He discusses the attempts of the United Nations Commission on International Trade Law (UNCITRAL) to establish a global, "liberal" secured credit law regime through its Legislative Guide, modelled on Article 9 of the US Uniform Commercial Code. His analysis is highly topical because easier access to more secure and thus cheaper credit is considered as a key lever for stimulating economic growth and tackling the financial crisis in the US and Eurozone member states. McCormack argues that a Polanyian perspective 
requires to pay greater attention to local social contexts that shape business transactions and the uptake of credit, as well as existing national credit laws. His article links in an innovative way sociology of law debates about the limits of legal transplants with an empirical economic sociology perspective that questions whether well-documented private property rights really are prerequisites for well-functioning markets in credit.

Thomas' article concludes the discussion in Part II of the special issue through a critical examination of co-operatives as a particular organisational form for facilitating and regulating business activity. She argues that some co-operatives can be perceived as an "epistemic community" that challenges policymakers and researchers to think more creatively and radically about regulating business activity. Industrial democracy, including changed social relationships between workers themselves, and more cooperative relationships between production units and the communities in which they are embedded, can constitute new forms of business self-regulation. She provides a fascinating account of the worker takeovers of factories in the aftermath of the Argentine debt crisis in 2001. In her analysis, disengagement from financial markets that are underpinned by private property is an important condition for the success of cooperatives, a point illustrated also by the experience of demutualisation of building societies in the 1980s in the UK.

The final part of this special issue examines the contribution of the concept of competition and competition law to the embedding of economic into social relationships. It thus further tackles the conundrum - touched upon in some of the articles in Part II that law's role in embedding economic into social relationships is ambiguous. Law can both disembed, but also re-embed economic into social relationships. It is also unclear which legal forms embed and which disembed. ${ }^{24}$ Competition law is a paradigmatic example here. It can, in Polanyian terms, disembed economic out of social relationships by promoting allocatively efficient and competitive self-regulating markets. It can also re-embed economic into social relationships when rendering uncompetitive behaviour lawful on public interest grounds. Moreover, as state regulation which seeks to reduce monopolistic business activity, competition law is part of the "double movement" that constitutes markets in the first place. Andriychuk starts the discussion in Part III by exploring economists' focus on perfect competition. He argues that, even though welfare economists reduce social interests to cost-benefit analysis, their analysis can still contribute to tackling the Polanyian challenge: how to actually achieve the embedding of economic relationships into social ones in order to maintain stability and social cohesion in societies. Andriychuk, however, concedes that the contribution of neoclassical economics is limited when its analytical claims about how markets operate become blurred with normative claims about how they should operate.

Stephan's article puts Andriychuk's abstract discussion into a concrete context by examining whether the approval of the merger between the two UK banks, Lloyds and HBOS, in the wake of the 2008 financial crisis, signalled the end of "economics-based" merger regulation. The merger was authorised by the Secretary of State for Business, with the consent of Parliament on the basis of a newly created public interest ground, "maintaining the stability of the UK financial system", though it had been opposed by the Office of Fair Trading on competition grounds. Departing from a Polanyian perspective,

24 This is an unresolved point in the contemporary economic sociology literature. Some contributors consider contract as disembedding because it promotes in Toennies' terms a shift from Gemeinschaft to Gesellschaft (K Gemici, "Karl Polanyi and the antinomies of embeddedness" (2008) 6(1) Socio-Economic Review 19) while others consider the negotiation of contractual terms in particular for long-term contracts as reducing the "marketness" of an economic transaction and thus as embedding economic relationships into the negotiated social contract norms (F Block, "Contradictions of self-regulating markets" in M Mendell, and D Salée, The Legacy of Karl Polanyi: Market, state and society at the end of the twentieth century (London: Macmillan 1991), p. 90. 
Stephan argues that this merger should be seen as exceptional and he therefore makes a case for competition law to maintain the operation of self-regulating markets.

Harker's article moves the discussion to a new cutting-edge field of economic activity, the development of new media markets. His article questions the value of competition in such markets, as championed by neoclassical economists. Limiting competition can, for instance, ensure that sufficient revenue is generated for broadcasters in order to pursue public service values that promote citizenship, social cohesion and cultural as well as educational objectives. Harker's article is a powerful illustration of Polanyi's idea of the "always embedded economy". He suggests that existing public service broadcasters, such as the $\mathrm{BBC}$, shape viewers' preferences and thus frame and embed the market also in new commercial broadcasting services. His analysis also further develops Polanyi's ideas by highlighting the contribution of modern technology to disembedding economic out of social relationships. Digital broadcasting, for instance, has accelerated the commodification of broadcasting services.

To conclude, the articles in this special issue provide fascinating and stimulating reading for regulation researchers and public policymakers who want to think about reforming business regulation in light of conceptual discussions about economy, society, state and law intersections in the developing field of the economic sociology of law. 
